\title{
Pengaruh Kualitas Situs Web, Nilai Hedonis, Dan Nilai Utilitarian Terhadap Niat Membeli Kembali
}

\author{
Dyan Febrina Kusumadewi ${ }^{1}$ \\ Noorlailie Soewarno ${ }^{2}$ \\ Isnalita $^{3}$
}
$1,2,3$
Fakultas Ekonomi dan Bisnis Universitas Airlangga (Unair),
Surabaya, Indonesia
e-mail: dyanfebrina@gmail.com

\begin{abstract}
ABSTRAK
Penelitian ini bertujuan untuk mengetahui pengaruh kualitas situs web, nilai hedonis, dan nilai utilitarian terhadap niat membeli kembali pada situs web Lazada. Penelitian ini menggunakan 107 responden pengguna Lazada yang dikumpulkan melalui survei online. Hasil penelitian ini menunjukkan bahwa dari tiga dimensi kualitas situs web, hanya kualitas informasi yang berpengaruh positif dan signifikan terhadap niat membeli kembali. Sedangkan kualitas sistem dan kualitas layanan tidak berpengaruh signifikan terhadap niat membeli kembali.Selain itu, nilai hedonis dan nilai utilitarian juga berpengaruh positif dan signifikan terhadap niat membeli kembali.

Kata kunci: Kualitas situs web, nilai hedonis, nilai utilitarian, niat membeli kembali.
\end{abstract}

\section{ABSTRACT}

This study aims to determine the impact of website's quality, hedonic value, and utilitarian value toward repurchaseintention on the Lazada marketplace. This study consisted of 107 respondents of Lazada users collected through online surveys. The results indicate that the quality of information has a positive and significant effect on repurchase intention. While the quality of the system and service quality have no significant effect on repurchase intention. In addition, hedonic values and utilitarian values have a positive and significant effect on repurchase intention.

Keywords: Website quality, hedonic value, utilitarian value, repurchase intention.

\section{PENDAHULUAN}

Pada era digital seperti sekarang ini, e-commerce merupakan hal yang lazim.

Dengan adanya e-commerce, banyak pelanggan yang beralih dari pembelian barang dengan cara tradisional, seperti melalui toko, ke pembelian barang melalui e-commerce. Meningkatnya jumlah pelanggan yang melakukan transaksi melalui 
Dyan Febrina Kusum adewi, Noorlailie Soewarno dan Isnalita. Pengaruh ...

e-commerce didorong oleh kemudahan, kecepatan, dan fleksibilitas cara bertransaksi. Pada tahun 2018, pengguna e-commerce di Indonesia mencapai 11,9\% dari jumlah populasi, meningkat dari tahun 2016 sebesar 9,6\% dan tahun 2017 sebesar 10,7\% (Putera, 2018). Perkembangan e-commerce yang pesat inimendorong perusahaan e-commerceuntuk memperhatikan kualitasnya, termasuk kualitas situs webnya, karena situs web yang menarik akan mendorong pelanggan untuk melakukan lebih banyak pembelian online (Hadaya et al, 2006) (Novak et al, 2000) (Poddar et al, 2009).

Menurut Rayport \& Jaworski (2003), seperti yang dikemukakan oleh Brown et al (2012) bahwa kualitas dari sebuah situs web dapat dilihat melalui beberapa atribut, seperti konteks, konten, commerce, kustomisasi, komunitas, dan komunikasi. Sedangkan Li, et al (2017), melihat kualitas situs web dari segi kegunaan, kemudahan penggunaan, entertainment, dan complementary. Situs web e-commerce mewakili kehadiran perusahaan secara online, sehingga kualitas situs web yang rendah dapat memberikan citra yang buruk pada perusahaan dan menghalangi niat pelanggan untuk melakukan pembelian atau kembali ke situs web (Kuan et al, 2008) (Nielsen, 2000). Sebagai contoh, situs web yang tidak dapat memberikan informasi yang lengkap terkait produk, situs web yang memiliki langkah-langkah atau navigasi yang sulit dipahami oleh pelanggan, serta customer service yang susah dihubungi, akan membuat pelanggan kesulitan dan ragu-ragu untuk bertransaksi melalui situs web tersebut sehingga dapat menyebabkan pelanggan enggan untuk melakukan pembelian kembali. 
Selain kualitas web, pembelian yang dilakukan oleh pelanggan juga dapat dipengaruhi oleh perilaku konsumen. Perilaku konsumen adalah hasil dari motif, sikap dan nilai-nilai dan dapat bermanifestasi dalam perilaku pembelian dan konsumsi (Khare, 2011). Perilaku konsumen ini dapat dikategorikan menjadi dua jenis, yaitu pelanggan yang berorientasi pada nilai hedonis dan pelanggan yang berorientasi pada nilai utilitarian.

Nilai-nilai hedonis terkait dengan pemuasan indera yang ditingkatkan melalui pengalaman kesenangan, hiburan, fantasi, dan playfulness (Babin, et al, 1994) (Bridges \& Florsheim, 2008) (Holbrook \& Hirschman, 1982) (Scarpi, 2012). Pelanggan dapat memperoleh nilai hedonis, melalui stimulasi/ gairah, permainan, dan pengaruh positif, misalnya kesenangan dan kegembiraan (Bridges \& Florsheim, 2008). Pada pelanggan yang berorientasi pada nilai hedonis, penggunaan produk dapat menciptakan rasa fantasi, menghasilkan perasaan berdasarkan indera, dan menghasilkan rangsangan emosional untuk memuaskan diri (J. Kang \& Poaps, 2010).Sedangkan menurut Fischer \& Arnold (2014) dan Khare (2011), pelanggan yang berorientasi pada nilai utilitarian melakukan pemilihan produk berdasarkan pada pengolahan informasi rasional dan analitis (. Nilai utilitarian diperoleh pelanggan jika mereka berfokus pada tujuan dan menerima kenyamanan, aksesibilitas, seleksi, ketersediaan informasi, dan tidak ada persyaratan untuk komitmen (Scarpi, 2012). Selain itu nilai utilitarian juga diperoleh dari fitur yang terkait dengan persepsi kemudahan penggunaan, kebebasan, dan kontrol (Bridges \& Florsheim, 2008). Pelanggan yang berorientasi pada nilai utilitarian tidak mudah terbujuk oleh diskon dan melakukan pembelian 
sesuai dengan kebutuhannya karena mereka berfokus pada tujuan dan kegunaan dari produk.

Menurut Chung (2015), nilai hedonis memberikan efek yang lebih kuat pada perilaku belanja daripada nilai utilitarian. Hal ini menyiratkan bahwa belanja melibatkan keputusan multisensor daripada keputusan kognitif. Nilai hedonis sangat lekat dengan pembeli kompulsif dimana menurut Kinney, et al (2016), pembeli kompulsif mengalami tingkat motivasi hedonis yang lebih tinggi saat berbelanja di situs web daripada pembeli non-kompulsif. Namun, menurut Bridges \& Florsheim (2008), hanya nilai utilitarian yang mempengaruhi peningkatan pembelian online, sedangkan nilai hedonis tidak terkait dengan peningkatan pembelian online.

Berdasarkan Teori Planned Behaviour, niat merupakan indikator perilaku karena adanya faktor motivasi yang memengaruhi perilaku. Hal ini merupakan indikator dari seberapa keras seseorang mau mencoba dan seberapa besar upaya yang mereka rencanakan ketika melakukan suatu perilaku (Ajzen, 1991). Menurut Ajzen (1991) munculnya niat ditentukan dari tiga komponen, yaitu (1) sikap terhadap perilaku- sikap seseorang terhadap hasil atau hasil dari melakukan perilaku; (2) tekanan sosial atau norma subyektif, pengaruh orang lain; (3) kontrol perilaku yang dirasakan adalah sejauh mana seseorang percaya dia memiliki kontrol atas kinerja perilaku dan merupakan keyakinan tentang ada atau tidaknya faktor-faktor yang memfasilitasi dan menghalangi individu untuk melakukan suatu perilaku. Pada penelitian ini, nilai utilitarian dan nilai hedonis berkaitan dengan kontrol perilaku karena nilai-nilai tersebut dapat mendorong atau 
memotivasi niat seseorang untuk melakukan pembelian kembali.

Di bidang perilaku konsumen, teori ini telah digunakan untuk menjelaskan akuisisi dan perubahan sikap terhadap kategori, produk, dan merek, serta sikap dan niat yang terkait dengan pembelian, pembelian ulang, penggunaan, dan penggunaan kembali produk dan jasa (Ajzen \& Fishbein, 2004). Jika komponen niat dikaitkan dengan niat membeli kembali, maka dapat disimpulkan bahwa seseorang akan memiliki sikap yang positif jika orang tersebut yakin bahwa sebuah tingkah laku dapat menghasilkan outcome yang positif. Apabila individu yakin perilaku membeli yang dilakukan akan menghasilkan outcome yang positif, maka individu tersebut memiliki sikap yang positif terhadap perilaku membeli yang akan mendorong mereka untuk melakukan pembelian kembali, begitupun sebaliknya. Selain itu, seseorang yang yakin bahwa kebanyakan orang yang mempengaruhinya menyetujui dirinya menampilkan perilaku membeli, dan adanya motivasi untuk melakukan perilaku membeli, akan menyebabkan individu tersebut memiliki tekanan pada dirinya untuk melakukan pembelian kembali terhadap suatu produk. Faktor-faktor seperti uang, transportasi, dan waktu merupakan kontrol perilaku seseorang untuk melakukan pembelian kembali atau tidak pada suatu produk.

Niat untuk membeli kembali berhubungan dengan retensi pelanggan yang mengacu pada sejauh mana situs web tersebut mampu menarik pelanggan situs web yang sudah ada untuk membeli lagi di masa depan (Ittner \& Larcker, 1998). Dapat dikatakan bahwa kualitas situs web merupakan faktor yang penting karena kualitas web berada di bawah kendali perusahaan dan merupakan cara 
memengaruhi niat perilaku dari pengguna (Ahnet al, 2007) dan mendorong niat pembelian mereka (Liang \& Chen, 2009).

Delone \& Mclean (2003) mengembangkan IS Success Model untuk mengukur kesuksesan sistem dari e-commerce dimana terdapat tiga dimensi, yaitu kualitas sistem, kualitas informasi, dan kualitas layanan. Kualitas sistem dapat diukur menggunakan kemudahan penggunaan, fungsi, keandalan, fleksibilitas, kualitas data, portabilitas, integrasi, dan kepentingan digunakan. Kualitas informasi dapat diukur menggunakan akurasi, ketepatan waktu, kelengkapan, relevansi, dan konsistensi. Kualitas layanan dapat diukur menggunakan bukti fisik, keandalan, daya tanggap, jaminan, dan empati.

Namun terdapat modifikasi yang dilakukan oleh beberapa peneliti terkait atribut dari dimensi IS Success Model pada penelitiannya. Lin (2007) menggunakan desain website dan interactivity untuk kualitas sistem; keamanan dan informasi untuk kualitas informasi; responsiveness, kepercayaan, dan empathy untuk kualitas layanan. Sedangkan Kuan et al.(2008), berdasarkan hasil mapping dari beberapa penelitian, mengemukakan kemudahan penggunaan, kemudahan navigasi, konsistensi tata letak, daya tarik visual, check out cepat, dan download delay sebagai atribut kualitas sistem; relevansi, keakuratan, ketepatan waktu, konten, format, kelengkapan, dan pemahaman sebagai atribut dari kualitas informasi; efektivitas pencarian dan perbandingan produk, interaktivitas, ketanggapan, kejelasan pada keamanan dan kebijakan privasi, jaminan, empati, dan pelacakan produk sebagai atribut dari kualitas service. 
Proses pembelian online terdiri dari dua konteks, yaitu proses pembelian online utilitarian (terencana) dan proses pembelian online hedonis (kompulsif) (Ozkara et al,2017). Nilai hedonis lebih bersifat pengalaman, sementara nilai utilitarian melibatkan penekanan informasi dan menyoroti proses konsumsi itu sendiri (Henry et al, 2004). Konsumen utilitarian bertujuan untuk memperoleh informasi produk dari produk yang ditargetkan untuk membuat keputusan berkualitas tinggi dan menyelesaikan tugas pembelian dengan tenggat waktu tertentu, sedangkan konsumen hedonis menerapkan perilaku penelusuran eksplorasi, yang 'tidak dipandu oleh sasaran atau hasil, tetapi oleh proses itu sendiri" (Wu et al, 2015). Hal ini konsisten dengan yang dikemukakan oleh Chung (2015) dimana dari pandangan utilitarian, konsumen mungkin ingin membeli produk secara efisien dan tepat waktu untuk mencapai tujuan mereka. Sebaliknya, dari pandangan hedonis, konsumen mungkin cenderung membenamkan diri dalam lingkungan belanja dan menikmati kegembiraan atau kesenangan selama proses "berburu".

Penelitian sebelumnya tentang kualitas situs web menggunakan kepuasan pengguna atau kepercayaan dari kualitas situs web sebagai ukuran pengganti untuk dampak kualitas situs web pada perilaku pembelian pelanggan. Menurut Lin (2007), desain situs web, interaktivitas, informasi, keamanan, dan kepercayaan, yang menjadi atribut kualitas situs web, mempengaruhi kepuasan pelanggan, sementara empati yang termasuk dalam kualitas layanan tidak memiliki pengaruh yang signifikan terhadap kepuasan pelanggan. Sedangkan Li et al(2017) mengemukakan bahwa kualitas situs web (kegunaan, kemudahan penggunaan, 
Dyan Febrina Kusum adewi, Noorlailie Soewarno dan Isnalita. Pengaruh ...

entertainment, dan complementary) mempengaruhi kepercayaan dan niat pemesanan online. Sementara itu, Hsu, Chen, \& Kumar(2016) mengemukakan bahwa kualitas sistem dan kualitas layanan merupakan anteseden penting dari kepuasan pelanggan, sedangkan kualitas informasi bukan merupakan anteseden dari kepuasan pelanggan. Namun, hal tersebut dapat mengarah pada kegagalan untuk membedakan dampak langsung dari kualitas situs web pada niat untuk membeli lagi dari situs web di masa depan (Kuan et al., 2008).

Penelitian ini menggabungkan kualitas situs web yang dimiliki oleh perusahaan e-commerce dengan nilai hedonis dan nilai utilitarian yang dimiliki oleh pelanggan terhadap niat membeli kembali. Dalam menilai kualitas situs web, penelitian ini menggunakan model Information System (IS) yang menilai kualitas situs web melalui tiga dimensi, yaitu kualitas sistem, kualitas informasi, dan kualitas layanan (Delone \& Mclean, 2003). Penelitian dilakukan pada pelanggan situs Lazada dimana menurut survey yang dilakukan iPrice (Setyowati, 2018), Lazada termasuk ke dalam lima besar e-commerce di Indonesia dan berada di posisi puncak marketplace dengan jumlah pengunjung tertinggi di kuartal 1 tahun 2018. Sedangkan untuk kuartal 4 tahun 2018, Lazada berada di posisi 4 marketplace dengan jumlah pengunjung yang meningkat sebesar 22 juta dari kuartal sebelumnya(Luthfi, 2019). 
Kualitas situs web yang bagus akan mempertahankan minat pelanggan untuk terus menavigasi situs web sehingga hal ini akan meningkatkan pengalaman pelanggan, dan pada akhirnya, meningkatkan kemungkinan pembelian di situs web (Kuan et al., 2008). Kinerja keseluruhan sistem situs web mewujudkan kualitas sistem dan dapat dirasakan pelanggan dalam berbelanja di penjual online (Lin, 2007). Kemampuan sistem memiliki dampak positif pada persepsi kemudahan penggunaan dan kegunaan situs web (Liao \& Cheung, 2002). Selain itu, menurut Zhou (2013), kualitas sistem mencerminkan tingkat kecepatan akses, kemudahan penggunaan, visual appeal, dan navigasi. Jika sistem situs web tidak dapat diandalkan, seperti tidak menyediakan layanan yang dapat diandalkan dan tidak terganggu, tidak menyediakan navigasi yang efektif dan menunjukkan tata letak yang tidak jelas, pengguna akan membentuk kesan yang buruk terhadap situs tersebut (Zhou \& Zhang, 2009). Hal ini akan menyebabkan pengguna menyerah menggunakan situs. Dengan demikian, hipotesis yang dikembangkan adalah:

$\mathrm{H}_{1}$ : Kualitas sistem berpegaruh positifterhadap niat membeli kembali.

Pengguna mengakses situs web e-commerce untuk memperoleh informasi terlebih dahulu dan melakukan transaksi di lain waktu (Zhou \& Zhang, 2009). Oleh karena itu, kualitas informasi yang dihasilkan oleh sistem dan transmisi merupakan faktor penting yang mempengaruhi kesuksesan sistem informasi (Lee \& Kozar, 2006). Kualitas informasi merupakan nilai yang dirasakan oleh pelanggan dari output yang dihasilkan oleh situs web (Lin, 2007). Jika informasi yang disajikan sesuai dengan harapan dan kebutuhan user berdasarkan dimensi kualitas informasi, maka informasi tersebut merupakan informasi yang 
berkualitas.Pelanggan akan menilai kualitas informasi yang disediakan oleh situs, dan membentuk kesan mereka terhadap situs (Zhou \& Zhang, 2009). Persepsi pelanggan tentang kualitas informasi dianggap mempengaruhi niat dan penerimaan mereka untuk menggunakan informasi web secara positif (Jeong \& Lambert, 2001). Menurut Delone \& Mclean(2003), kualitas informasi memiliki beberapa karakteristik, yaitu akurasi, ketepatan waktu, kelengkapan, relevansi, dan konsistensi. Tingkat kualitas informasi yang tinggi cenderung memberikan kenyamanan, kesenangan yang ditingkatkan, dan keputusan pembelian yang lebih baik kepada pengguna (Ahn et al., 2007). Dengan demikian, hipotesis yang dikembangkan adalah:

$\mathrm{H}_{2}$ : Kualitas informasi berpengaruh positifterhadap niat membeli kembali.

Dimensi ketiga dari kualitas situs web adalah kualitas layanan yang mengacu pada evaluasi individu terhadap kualitas layanan online yang disampaikan melalui situs web termasuk keandalan, daya tanggap, jaminan, dan personalisasi (Chen et al, 2015) ( Zhou, 2013). Selain itu, kualitas layanan untuk perusahaan berbasis web bergantung pada penyediaan berbagai mekanisme komunikasi untuk menerima keluhan pengguna dan penyelesaiannya secara tepat waktu; itu juga melibatkan membantu pengguna menjadi efektif, menyarankan produk atau layanan pelengkap, dan bersama-sama memecahkan masalah (Ahn et al., 2007). Alat-alat yang dapat meningkatkan layanan pelanggan diantaranya halaman web yang dipersonalisasi, daftar pertanyaan yang sering diajukan dan helpdesks berbasis web (Kuan et al., 2008). Kualitas layanan harus menyediakan semua layanan dalam proses pembelian (menemukan, memesan, dan mengirimkan 
produk) (Ahn et al., 2007). Oleh karena itu, kualitas layanan semakin diakui memainkan peran penting dalam mempengaruhi niat pembelian pelanggan online karena kualitas layanan yang baik akan memberikan kepuasan pada pelanggan yang pada akhirnya mendorong pelanggan untuk melakukan pembelian kembali (Lin, 2007) (Tandon et al, 2017). Dengan demikian, hipotesis yang dikembangkan adalah:

$\mathrm{H}_{3}$ : Kualitas layanan berpengaruh positif terhadap niat membeli kembali.

Dalam melakukan pembelian, terdapat dua kategori perilaku konsumen, yaitu pelanggan yang berorientasi pada nilai utilitarian dan pelanggan yang berorientasi pada nilai hedonis. Pelanggan yang berorientasi pada nilai utilitarian melakukan pemilihan produk berdasarkan pada pengolahan informasi rasional dan analitis (Fischer \& Arnold, 2014). Dalam pandangan utilitarian, konsumen fokus dengan pembelian produk secara efisien dan tepat waktu untuk mencapai tujuan mereka (Ryu \& Han, 2010). Hal ini konsisten dengan yang dikemukakan oleh Babin et al.(1994) dimana nilai utilitarian tergantung pada apakah konsumsi tertentu dapat mendorong tercapainya pengalaman berbelanja dimana suatu produk dibeli dengan cara yang disengaja dan efisien. Sedangkan pada pelanggan yang berorientasi pada nilai hedonis, penggunaan produk dapat menciptakan rasa fantasi, menghasilkan perasaan berdasarkan indera, dan menghasilkan rangsangan emosional untuk memuaskan diri (J. Kang \& Poaps, 2010). Nilai hedonis mencerminkan hiburan belanja dan potensi emosional yang dihasilkan dari pengalaman yang menyenangkan versus pencapaian tujuan yang ditentukan sebelumnya (Babin et al., 1994) .Menurut Bridges \& Florsheim (2008), 
peningkatan pembelian online hanya dipengaruhi oleh nilai utilitarian saja. Sedangkan menurut Khare (2011) nilai utilitarian dan nilai hedonis dari konsumen mempengaruhi sikap dan perilaku belanja mereka. Demikian pula dengan penelitian yang dilakukan oleh Chung (2015) dimana nilai belanja utilitarian dan nilai belanja hedonis memberikan efek terhadap perilaku belanja. Hal ini konsisten dengan yang dikemukakan oleh Holbrook \& Hirschman (1982) dimana konsumen dapat termotivasi untuk membeli produk dan layanan sesuai dengan nilai utilitarian dan hedonis yang dirasakan oleh konsumen. Dengan demikian, hipotesis yang dikembangkan adalah:

$\mathrm{H}_{4}$ : Nilai hedonis berpengaruh positif terhadap niat membeli kembali.

$\mathrm{H}_{5}$ : Nilai utilitarian berpengaruh positif terhadap niat membeli kembali.

\section{METODE PENELITIAN}

Penelitian ini menggunakan dimensi model IS (kualitas sistem, kualitas informasi, dan kualitas layanan) yang dikembangkan oleh Delone \& Mclean(2003) untuk mengukur kualitas situs web. Atribut kualitas pada penelitian ini adalah atribut kualitas menurut Barreto \& Martínez (2018), Kuan et al. (2008); Lin (2007) dan Tandon et al. (2017). Atribut kualitas sistem yang digunakan adalah kemudahan penggunaan, kemudahan navigasi, interactivity, dan konsistensi layout; atribut kualitas informasi adalah relevan, akurat, timeliness, konten, completness, dan mudah dimengerti; atribut kualitas layanan adalah keefektifan pencarian produk, perbandingan produk, responsiveness, product tracking, assurance, empathy, dan kejelasan tentang keamanan dan kebijakan privasi . 
Nilai utilitarian diukur melalui pencapaian, fokus pada tujuan, dan efektifitas (Bridges \& Florsheim, 2008). Sedangkan nilai hedonis diukur melalui pengalaman kesenangan, hiburan, playfulness, dan nilai (diskon dan harga yang murah) ( Fischer \& Arnold, 2014). Repurchase intention atau niat membeli ulang diukur dengan berencana membeli lagi, lebih sering membeli, dan merekomendasikan kepada orang lain ( Ladhari, 2009). Tanggapan dari peserta survei untuk masing-masing item diukur pada skala Likert 5 poin, mulai dari 1 (= 'sangat tidak setuju'), 2 (= 'tidak setuju'), 3 (= 'kurang setuju'), 4 (='setuju') hingga 5 (= 'sangat setuju').

Untuk memudahkan dalam proses analisis data, penelitian ini menggunakan 107 responden yang merupakan pengguna situs belanja online Lazada. Untuk teknik penarikan sampel ditetapkan secara non probability sampling yaitu dengan purposive sampling, dimana tidak memberi peluang atau kesempatan sama bagi setiap anggota populasi untuk dipilih menjadi sampel karena harus memiliki kriteria pernah melakukan pembelian produk di situs belanja online Lazada.

Teknik analisis data yang digunakan dalam penelitian adalah teknik analisis regresi linier berganda. Model persamaan regresi linier berganda pada penelitian ini adalah:

$$
Y=\alpha+\beta_{1} X_{1}+\beta_{2} X_{2}+\beta_{3} X_{3}+\beta_{4} X_{4}+\beta_{5} X_{5}+e
$$

Keterangan:

\begin{tabular}{|c|c|}
\hline Y & $=$ niat membeli kembali \\
\hline$\alpha$ & $=$ konstanta \\
\hline $\mathrm{X}_{1}$ & $=$ kualitas sistem \\
\hline $\mathrm{X}_{2}$ & $=$ kualitas informasi \\
\hline$X_{3}$ & $=$ kualitas layanan \\
\hline $\mathrm{X}_{4}$ & $=$ nilai hedonis \\
\hline $\mathrm{X}_{5}$ & $=$ nilai utilitarian \\
\hline
\end{tabular}


Dyan Febrina Kusum adewi, Noorlailie Soewarno dan Isnalita. Pengaruh ...

$\beta_{1}, \beta_{2}, \beta_{3}, \beta_{4}, \beta_{5}=$ koefisien regresi

\section{HASIL DAN PEMBAHASAN}

Penelitian ini bertujuanuntuk mengetahui pengaruh kualitas situs web, nilai hedonis, dan nilai utilitarian terhadap niat membeli kembali pada situs web Lazada. Data dikumpulkan melalui survei secara online dimana terdapat 107 responden dalam penelitian ini. Tabel 1 menggambarkan karakteristik responden yang berpartisipasi dalam penelitian ini. Karakteristik responden menerangkan jenis kelamin, umur, pendidikan, dan status pekerjaan responden.

Tabel 1.

Karakteristik Responden

\begin{tabular}{llll}
\hline No & Kriteria & Jumlah (orang) & Persentase (\%) \\
\hline 1. & Jenis Kelamin & 39 & \\
& Pria & 68 & 36,45 \\
& Wanita & 107 & 63,55 \\
& Total & & 100 \\
2. & Usia & 15 & \\
& $<20$ tahun & 62 & 14,02 \\
& 20-29 tahun & 21 & 57,94 \\
& 30-39 tahun & 9 & 19,63 \\
& $>39$ tahun & 107 & 8,41 \\
& Total & & 100 \\
3. Pendidikan & 19 & \\
& <D1 & 4 & 17,76 \\
& D3 & 68 & 3,74 \\
& S1 & 16 & 63,55 \\
& S2 & 107 & 14,95 \\
& Total & & 100 \\
S. & Status Pekerjaan & 67 & \\
& Bekerja & 40 & 62,62 \\
& Tidak Bekerja & 107 & 37,38 \\
& Total & & 100 \\
\hline
\end{tabular}

Sumber: Data diolah, 2019

Tabel 1 menunjukkan bahwa berdasarkan jenis kelamin jumlah responden pria sebanyak 39 orang $(36,45 \%)$ dan responden wanita sebanyak 68 orang (63,55\%).Hal ini menunjukkan bahwa mayoritas responden berjenis kelaminwanita. 
Berdasarkan usia, responden dengan usia dibawah 20 tahun sebanyak 15 orang (14,02\%), usia 20-29 tahun sebanyak 62 orang (57,94\%), usia 30-39 tahun sebanyak 21 orang $(19,83 \%)$, dan usia diatas 39 tahun sebanyak 9 orang $(8,41 \%)$. Hal ini menunjukkan bahwa mayoritas responden berusia antara 20-29 tahun. Berdasarkan pendidikan terakhir, responden dengan tingkat pendidikan Diploma 1 atau dibawahnya sebanyak 19 orang $(17,76 \%)$, Diploma 3 sebanyak 4 orang (3,74\%), S1 sebanyak 68 orang $(63,55 \%)$, dan S2 sebanyak 16 orang (14,95\%). Hal ini menunjukkan bahwa mayoritas responden adalah responden dengan pendidikan terakhir pada jenjang S1. Berdasarkan status pekerjaan, responden yang bekerja sebanyak 67 orang $(62,62 \%)$,sedangkan yang tidak bekerja sebanyak40 orang (37,38\%). Hal ini menunjukkan bahwa mayoritas responden telah bekerja.

Pengujian validitas dilakukan dengan responden sebanyak 107 responden. Dalam pengujian ini koefisien korelasi kritis diperoleh dari tabel distribusi $r$ dengan menggunakan tarif signifikansi sebesar 5\% maka r-tabel $=0,1882$. Hasil uji validitas menyatakan bahwa nilai $r_{x y}>0,1882$, sehingga seluruh pertanyaan dalam kuesioner pada item-item pertanyaan pada variabel Kualitas Sistem $\left(\mathrm{X}_{1}\right)$, Kualitas Informasi $\left(\mathrm{X}_{2}\right)$, Kualitas Layanan $\left(\mathrm{X}_{3}\right)$, Nilai Hedonis $\left(\mathrm{X}_{4}\right)$, Nilai Utilitarian $\left(\mathrm{X}_{5}\right)$, Niat Membeli Kembali (Y)adalah valid. 
Tabel 2.

Hasil Uji Validitas Item-item Variabel

\begin{tabular}{|c|c|c|c|c|c|}
\hline No & Variabel & $\begin{array}{c}\text { Kode } \\
\text { Instrumen }\end{array}$ & $\mathrm{r}_{\mathrm{xy}}$ & r-tabel & Keterangan \\
\hline \multirow[t]{5}{*}{1.} & Kualitas Sistem $\left(\mathrm{X}_{1}\right)$ & $\mathrm{X}_{1.1}$ & 0,746 & 0,1882 & Valid \\
\hline & & $\mathrm{X}_{1.2}$ & 0,778 & 0,1882 & Valid \\
\hline & & $\mathrm{X}_{1.3}$ & 0,626 & 0,1882 & Valid \\
\hline & & $\mathrm{X}_{1.4}$ & 0,771 & 0,1882 & Valid \\
\hline & & $\mathrm{X}_{1.5}$ & 0,769 & 0,1882 & Valid \\
\hline \multirow[t]{5}{*}{2.} & Kualitas Informasi $\left(\mathrm{X}_{2}\right)$ & $\mathrm{X}_{2.1}$ & 0,816 & 0,1882 & Valid \\
\hline & & $\mathrm{X}_{2.2}$ & 0,713 & 0,1882 & Valid \\
\hline & & $\mathrm{X}_{2.3}$ & 0,874 & 0,1882 & Valid \\
\hline & & $\mathrm{X}_{2.4}$ & 0,786 & 0,1882 & Valid \\
\hline & & $\mathrm{X}_{2.5}$ & 0,809 & 0,1882 & Valid \\
\hline \multirow[t]{9}{*}{3.} & Kualitas Layanan $\left(\mathrm{X}_{3}\right)$ & $\mathrm{X}_{3.1}$ & 0,621 & 0,1882 & Valid \\
\hline & & $\mathrm{X}_{3.2}$ & 0,589 & 0,1882 & Valid \\
\hline & & $\mathrm{X}_{3.3}$ & 0,702 & 0,1882 & Valid \\
\hline & & $\mathrm{X}_{3.4}$ & 0,614 & 0,1882 & Valid \\
\hline & & $\mathrm{X}_{3.5}$ & 0,611 & 0,1882 & Valid \\
\hline & & $\mathrm{X}_{3.6}$ & 0,658 & 0,1882 & Valid \\
\hline & & $\mathrm{X}_{3.7}$ & 0,518 & 0,1882 & Valid \\
\hline & & $\mathrm{X}_{3.8}$ & 0,596 & 0,1882 & Valid \\
\hline & & $\mathrm{X}_{3.9}$ & 0,624 & 0,1882 & Valid \\
\hline \multirow[t]{3}{*}{4.} & Nilai Hedonis $\left(\mathrm{X}_{4}\right)$ & $\mathrm{X}_{4.1}$ & 0,641 & 0,1882 & Valid \\
\hline & & $\mathrm{X}_{4.2}$ & 0,902 & 0,1882 & Valid \\
\hline & & $\mathrm{X}_{4.3}$ & 0,851 & 0,1882 & Valid \\
\hline \multirow[t]{4}{*}{5.} & Nilai Utilitarian $\left(\mathrm{X}_{5}\right)$ & $\mathrm{X}_{5.1}$ & 0,693 & 0,1882 & Valid \\
\hline & & $\mathrm{X}_{5.2}$ & 0,834 & 0,1882 & Valid \\
\hline & & $\mathrm{X}_{5.3}$ & 0,834 & 0,1882 & Valid \\
\hline & & $\mathrm{X}_{5.4}$ & 0,750 & 0,1882 & Valid \\
\hline \multirow[t]{4}{*}{6.} & Niat Membeli Kembali (Y) & $\mathrm{Y}_{1.1}$ & 0,706 & 0,1882 & Valid \\
\hline & & $\mathrm{Y}_{1.2}$ & 0,825 & 0,1882 & Valid \\
\hline & & $\mathrm{Y}_{1.3}$ & 0,872 & 0,1882 & Valid \\
\hline & & $\mathrm{Y}_{1.4}$ & 0,832 & 0,1882 & Valid \\
\hline
\end{tabular}

Sumber: Data diolah, 2019

Hasil uji reliabilitaspada tabel 3 menyatakan bahwa koefisien Cronbach's Alpha $>0,60$ sehingga seluruh pertanyaan dalam kuesioner pada item-item pertanyaan pada variabel Kualitas Sistem, Kualitas Informasi, Kualitas Layanan, Nilai Hedonis, Nilai Utilitarian, dan Niat Membeli Kembali adalah reliabel. 
Tabel 3.

Hasil Uji Reliabilitas

\begin{tabular}{lccc}
\hline \multicolumn{1}{c}{ Variabel } & Cronbach's Alpha & Nilai Kritis & Keterangan \\
\hline Kualitas Sistem & 0,787 & $\geq 0,60$ & Reliabel \\
Kualitas Informasi & 0,857 & $\geq 0,60$ & Reliabel \\
Kualitas Layanan & 0,785 & $\geq 0,60$ & Reliabel \\
Nilai Hedonis & 0,720 & $\geq 0,60$ & Reliabel \\
Nilai Utilitarian & 0,777 & $\geq 0,60$ & Reliabel \\
Niat Membeli Kembali & 0,821 & $\geq 0,60$ & Reliabel \\
\hline
\end{tabular}

Sumber: Data diolah, 2019

Hasil regresi linier berganda pada penelitian ini disajikan pada tabel 4 , sebagai berikut:

Tabel 4.

Hasil Regresi Linier Berganda

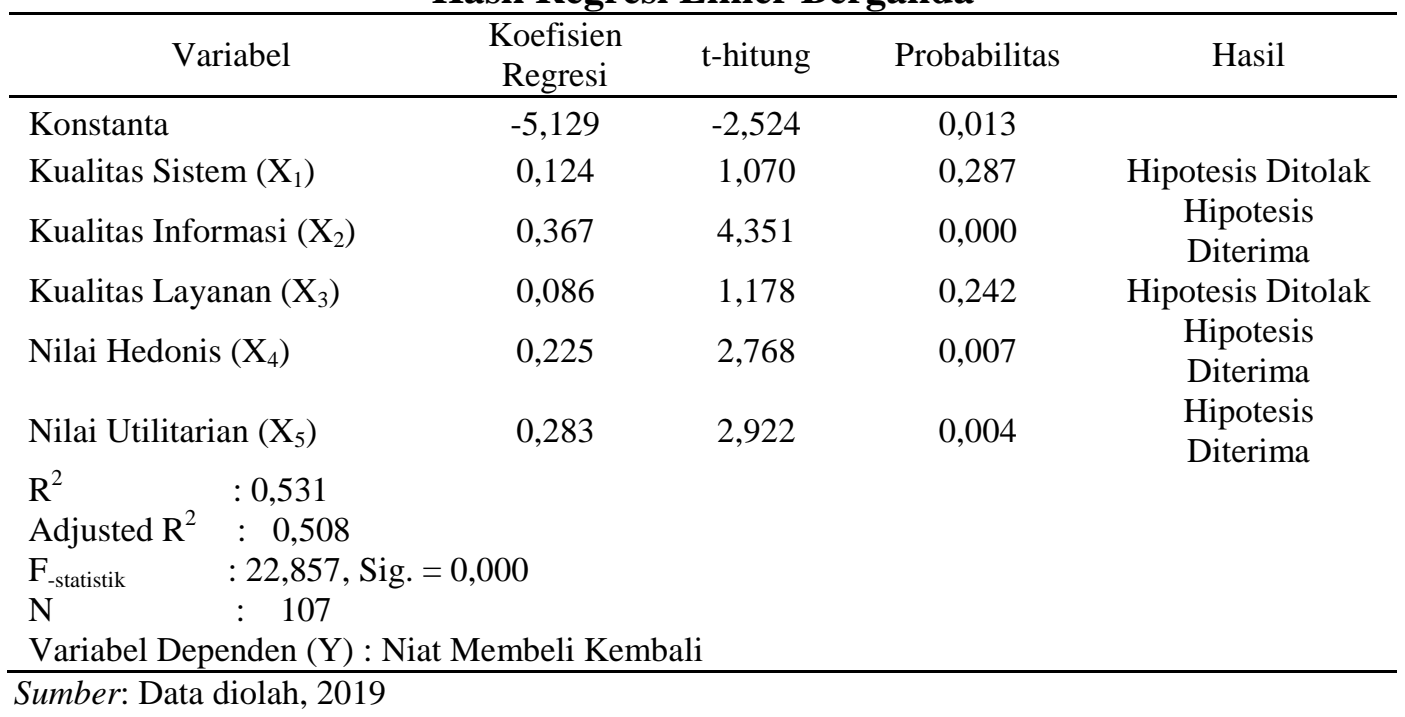

Berdasarkan hasil perhitungan dengan menggunakan program statistik komputer SPSS for Windows version 20 diperoleh hasil persamaan Regresi Linier Berganda sebagai berikut:

$$
Y=-5,129+0,124 X_{1}+0,367 X_{2}+0,086 X_{3}+0,225 X_{4}+0,283 X_{5}
$$

Koefisien regresi kualitas sistem $\left(\beta_{1}\right)$ mempunyai pengaruh positif terhadap niat membeli kembali, dengan koefisien regresi sebesar 0,124.Dengan adanya pengaruh yang positif, menunjukkan bahwa antara kualitas sistem dan niat 
membeli kembali menunjukkan hubungan yg searah, serta di dapat t-hitung sebesar 1,070 dan probabilitas 0,287.

Koefisien regresi kualitas informasi $\left(\beta_{2}\right)$ mempunyai pengaruh positif terhadap niat membeli kembali, dengan koefisien regresi sebesar 0,367.Dengan adanya pengaruh yang positif, menunjukkan bahwa antara kualitas informasi dan niat membeli kembali menunjukkan hubungan yg searah, serta di dapat t-hitung sebesar 4,351 dan probabilitas 0,000 .

Koefisien regresi kualitas layanan $\left(\beta_{3}\right)$ mempunyai pengaruh positif terhadap dan niat membeli kembali, dengan koefisien regresi sebesar 0,086.Dengan adanya pengaruh yang positif, menunjukkan bahwa antara kualitas layanan dan dan niat membeli kembali menunjukkan hubungan yg searah, serta di dapat t-hitung sebesar 1,178 dan probabilitas 0,242.

Koefisien regresi nilai hedonis $\left(\beta_{4}\right)$ mempunyai pengaruh positif niat membeli kembali, dengan koefisien regresi sebesar 0,225.Dengan adanya pengaruh yang positif, menunjukkan bahwa antara nilai hedonis dan niat membeli kembali menunjukkan hubungan yg searah, serta di dapat t-hitung sebesar 2,768 dan probabilitas 0,007 .

Koefisien regresi nilai utilitarian $\left(\beta_{5}\right)$ mempunyai pengaruh positif terhadap niat membeli kembali, dengan koefisien regresi sebesar 0,283.Dengan adanya pengaruh yang positif, menunjukkan bahwa antara nilai utilitarian dan niat membeli kembali menunjukkan hubungan yg searah, serta di dapat t-hitung sebesar 2,922 dan probabilitas 0,004 . 
Nilai $\mathrm{R}^{2}$ (Koefisien Determinasi) mempunyai range antara 0-1.Semakin besar $\mathrm{R}^{2}$ mengindikasikan semakin besar kemampuan variabel independen dalam menjelaskan variabel dependen.Pada hasil dari uji regresi linier berganda diperoleh $\mathrm{R}^{2}$ (Koefisien Determinasi) sebesar 53,1\%, artinya niat untuk bertransaksi menggunakan e-commerce dipengaruhi oleh kualitas sistem, kualitas informasi, kualitas layanan, nilai hedonis, dan nilai utilitarian, sedangkan sisanya 46,9\% dijelaskan oleh variabel lain di luar model penelitian ini.

Penelitian ini menggunakan level of significant $5 \%(0,05)$ dimana hasil pengujian pada tabel 4 menunjukkan bahwa variabel kualitas sistem $\left(\mathrm{X}_{1}\right)$ tidak berpengaruh signifikan terhadap niat membeli kembali (Y). Menurut Yang (2007), dalam melakukan transaksi online, pelanggan tidak terlalu memperhatikan kualitas sistem. Hal ini konsisten dengan yang dikemukakan oleh Schaupp et al.(2009) bahwa dalam melakukan transaksi online, yang terpenting bagi pelanggan adalah pelanggan dapat melakukan transaksi dan transaksi tersebut berhasil sehingga pelanggan cenderung kurang memperhatikan kualitas sistem. Pada dasarnya, pelanggan cenderung tidak memperhatikan kualitas sistem secara detail dimana kualitas sistem situs web Lazada cenderung sama dengan kualitas sistem situs web e-commerce yang lainnya.

Hasil regresi linier berganda pada tabel 4 juga menunjukkan bahwa variabel kualitas informasi $\left(\mathrm{X}_{2}\right)$ berpengaruh positif dan signifikan terhadap niat membeli kembali (Y). Pelanggan menggunakan informasi yang disediakan oleh situs web untuk mendapatkan informasi yang lengkap mengenai produk dan kualitasnya Kuan et al., 2008). Pelanggan akan menilai kualitas informasi yang disediakan 
oleh situs, dan membentuk kesan mereka terhadap situs (Zhou \& Zhang, 2009). Kesan yang baik terhadap kualitas informasi situs web akan mendorong pelanggan untuk melakukan pembelian kembali pada situs web yang sama. Hal ini konsisten seperti yang dikemukakan oleh Tsao et al., (2016) bahwa situs web belanja yang menawarkan kualitas informasi yang baik akan dapat menarik konsumen. Situs web Lazada memberikan informasi yang akurat, lengkap dan jelas terkait dengan produk dan kualitas produk yang dibutuhkan oleh pelanggan dalam pengambilan keputusan untuk melakukan pembelian.

Analisi regresi linier berganda pada dimensi kualitas website yang lain, yaitu kualitas layanan menunjukkan bahwa kualitas layanan $\left(\mathrm{X}_{3}\right)$ tidak berpengaruh signifikan terhadap niat membeli kembali (Y). Hal ini bertolak belakang dengan penelitian yang dilakukan oleh Pee, Jiang, \& Klein(2018) dan Tandon et al. (2017) dimana kualitas layanan berpengaruh terhadap niat membeli kembali. Kualitas layanan Lazada seperti customer service, FAQ, keamanan, privasi serta adanya umpan balik terhadap web, layanan, dan produk, cenderung sama dengan yang dimiliki oleh situs web e-commerce yang lainnya sehingga kualitas layanan tidak berpengaruh terhadap niat membeli kembali.

Terkait dengan perilaku konsumen, baik nilai hedonis $\left(\mathrm{X}_{4}\right)$ maupun nilai utilitarian $\left(\mathrm{X}_{5}\right)$ berpengaruh terhadap niat membeli kembali $(\mathrm{Y})$. Hasil penelitian ini sesuai dengan penelitian yang dilakukan oleh Chiu, Wang, Fang, \& Huang (2012) dimana nilai utilitarian dan nilai hedonis secara positif terkait dengan niat pembelian ulang. Ketika pengguna merasakan nilai utilitarian dari penggunaan situs web, misalnya, pengguna dapat dengan cepat dan nyaman menemukan 
produk yang disukai, atau merasa bahwa produk tersebut bernilai baik untuk uang, mereka lebih mungkin menghasilkan kepuasan terhadap situs, dan mendorong pembelian kembali (Gan \& Wang, 2017) (Vijay et al, 2017). Demikian pula ketika pengguna menikmati berbelanja atau menerima pengalaman yang baik dari menggunakan situs web, yaitu, mereka merasakan nilai hedonis yang lebih besar, mereka akan lebih terpuaskan dan niat mereka untuk membeli kembali melalui situs akan kuat.Oleh karena itu, nilai utilitarian dan nilai hedonis dapat menjadi kontrol perilaku konsumen dalam melakukan pembelian kembali dan nilai-nilai tersebut dapat digunakan untuk memprediksi perilaku belanja konsumen dimana sikap positif terhadap nilai utilitarian dan nilai hedonis meningkatkan niat pembelian kembaliyang terbentuk melalui persepsi konsumen terhadap produk (S. H. Hsu \& Bayarsaikhan, 2012) (Meitiana, 2017).

\section{SIMPULAN}

Menjamurnya e-commerce belakangan ini harus menjadi perhatian bagi Lazada agar dapat memenangkan persaingan bisnis. Dari ketiga dimensi kualitas situs web, hanya kualitas informasi saja yang berpengaruh terhadap niat membeli kembali pada situs web Lazada. Lazada harus dapat meningkatkan kualitas situs webnya. Situs web lazada harus memiliki sesuatu yang unik dan berbeda yang tidak dimiliki oleh situs web e-commerce yang lain, misalnya customer service yang dapat terhubung langsung melalui situs webnya. Selain itu, Lazada juga harus memperhatikan pelanggan yang berorientasi terhadap nilai utilitarian. Lazada harus dapat memberikan nilai utilitarian yang memadai kepada pelanggan karena kendali nilai utiltarian terdapat pada penjual (Chiu et al., 2012). 
Dyan Febrina Kusum adewi, Noorlailie Soewarno dan Isnalita. Pengaruh ...

Selain itu, Lazada juga tidak boleh mengabaikan pelanggan yang berorientasi pada nilai hedonis karena nilai-nilai hedonis seperti playfulness, kesenangan, pengalaman, menghilangkan stres, dan interaksi sosial, dapat mendorong pembelian. Memberikan manfaat seperti itu kepada pelanggan dapat meningkatkan niat pelanggan untuk membeli kembali melali situs web yang sama (Chiu et al., 2012). Penelitian ini hanya dilakukan pada pengguna dari satu situs web saja, yaitu pengguna Lazada sehingga untuk penelitian selanjutnya dapat digunakan beberapa e-commerce agar dapat diperoleh hasil yang lebih general. Selain itu, dapat pula melibatkan dua negara yang berbeda agar dapat lebih diketahui perbedaan perilaku konsumennya.

\section{REFERENSI}

Ahn, T., Ryu, S., \& Han, I. (2007). The impact of Web quality and playfulness on user acceptance of online retailing. Information \& Management, 44, 263275. https://doi.org/10.1016/j.im.2006.12.008

Ajzen, I. (1991). The Theory of Planned Behavior. Organizational Behavior and Human Decision Processes, 50, 179-221.

Ajzen, I., \& Fishbein, M. (2004). Questions Raised by a Reasoned Action Approach : Comment on Ogden ( 2003 ). Health Psychology, 23(4), 431434. https://doi.org/10.1037/0278-6133.23.4.431

Babin, B. J., Darden, W. R., \& Griffin, M. (1994). Work and/or Fun: Measuring Hedonic and Utilitarian Shopping Value. Journal of Consumer Research, 20, 644-656.

Barreto, J. J., \& Martínez, S. C. (2018). Destination website quality, users ' attitudes and the willingness to participate in online co-creation experiences. European Journal of Management and Business Economics. https://doi.org/10.1108/EJMBE-11-2017-0048

Bridges, E., \& Florsheim, R. (2008). Hedonic and utilitarian shopping goals : The online experience $\downarrow$. Journal of Business Research, 61, 309-314. 
https://doi.org/10.1016/j.jbusres.2007.06.017

Brown, C. V, DeHayes, D. W., Hotter, J. A., Martin, E. W., \& Perkins, W. C. (2012). Managing Information Technology (seventh ed). New Jersey: Prentice Hall.

Chen, X., Huang, Q., Davison, R. M., \& Hua, Z. (2015). What Drives Trust Transfer? The Moderating Roles of Seller-Specific and General Institutional Mechanisms. International Journal of Electronic Commerce, 20(2), 261289. https://doi.org/10.1080/10864415.2016.1087828

Chiu, C., Wang, E. T. G., Fang, Y., \& Huang, H. (2012). Understanding customers' repeat purchase intentions in B2C e-commerce: the roles of utilitarian value, hedonic value and perceived risk. Information Systems Journal, 1-30. https://doi.org/10.1111/j.1365-2575.2012.00407.x

Chung, Y. (2015). Journal of Air Transport Management Hedonic and utilitarian shopping values in airport shopping behavior. Journal of Air Transport Management, 49, 28-34. https://doi.org/10.1016/j.jairtraman.2015.07.003

Delone, W. H., \& Mclean, E. R. (2003). The DeLone and McLean Model of Information Systems Success : A Ten-Year Update. Journal of Management Information System, 9(4), 9-30. https://doi.org/10.1080/07421222.2003.11045748

Fischer, E., \& Arnold, S. J. (2014). More than a Labor of Love : Gender Roles and Christmas Gift Shopping. Journal of Consumer Research, 17(February 1990). https://doi.org/10.1086/208561

Gan, C., \& Wang, W. (2017). The influence of perceived value on purchase intention in social commerce context. Internet Research.

Hadaya, P., Talbot, J., Cadieux, J., \& Jean, E. (2006). B2C web site quality and emotions during online shopping episodes : An empirical study. Information \& Management, 43, 627-639. https://doi.org/10.1016/j.im.2006.03.004

Henry, A., Nigel, P., Linda, B., \& Kevin, V. (2004). Consumer behavior: a strategic approach. Boston: Houghton Mifflin Company.

Holbrook, M. B., \& Hirschman, E. C. (1982). The Experiential Aspects of Consumption: Consumer Fantasies, Feeiings, and Fun. Journal of Consumer Research, 9(September), 132-141.

Hsu, C., Chen, M., \& Kumar, V. (2016). How social shopping retains customers? Capturing the essence of website quality and relationship quality. Total Quality Management \& Business Excellence. 
https://doi.org/10.1080/14783363.2016.1171706

Hsu, S. H., \& Bayarsaikhan, B. E. (2012). Factors Influencing on Online Shopping Attitude and Intention of Mongolian Consumers. The Journal of International Management Studies, 7(2), 167-176.

Ittner, C. D., \& Larcker, D. F. (1998). Are Nonfinancial Measures Leading Indicators of Financial Performance? An Analysis of Customer Satisfaction. Journal of Accounting Research, 36, 1-35.

Jeong, M., \& Lambert, C. U. (2001). Adaptation of an information quality framework to measure customers ' behavioral intentions to use lodging Web sites. International Journal of Hospitality Management, 20, 129-146.

Kang, J., \& Poaps, H. P. (2010). Hedonic and Utilitarian Shopping Motivations of Fashion Leadership. Journal of Fashion Marketing and Management, 14(2), 312-328. https://doi.org/10.1108/13612021011046138

Khare, A. (2011). Influence of hedonic and utilitarian values in determining attitude towards malls : A case of Indian small. Journal of Retail \& Leisure Property, 9(5), 429-442. https://doi.org/10.1057/rlp.2011.6

Kinney, M. K., Scheinbaum, A. C., \& Schaefers, T. (2016). Compulsive buying in online daily deal settings: An investigation of motivations and contextual elements. Journal of Business Research, 69(2), 691-699. https://doi.org/10.1016/j.jbusres.2015.08.021

Kuan, H., Bock, G., \& Vathanophas, V. (2008). Comparing the effects of website quality on customer initial purchase and continued purchase at e- commerce websites. Behaviour \& Information Technology, 27(1), 3-16. https://doi.org/10.1080/01449290600801959

Ladhari, R. (2009). Service quality, emotional satisfaction , and behavioural intentions: A study in the hotel industry. Managing Service Quality, 19(3), 308-331. https://doi.org/10.1108/09604520910955320

Lee, Y., \& Kozar, K. A. (2006). Investigating the effect of website quality on ebusiness success : An analytic hierarchy process ( AHP) approach. Decision Support Systems, 42, 1383-1401. https://doi.org/10.1016/j.dss.2005.11.005

Li, L., Peng, M., Jiang, N., \& Law, R. (2017). International Journal of Hospitality Management An empirical study on the influence of economy hotel website quality on online booking intentions $\Sigma_{a}$. International Journal of Hospitality Management, 63, 1-10. https://doi.org/10.1016/j.ijhm.2017.01.001

Liang, C., \& Chen, H. (2009). A study of the impacts of website quality on 
customer relationship performance. Total Quality Management \& Business Excellence, 20(9), 971-988. https://doi.org/10.1080/14783360903181784

Liao, Z., \& Cheung, M. T. (2002). Internet-based e-banking and consumer attitudes : an empirical study. Information \& Management, 39, 283-295.

Lin, H. (2007). The Impact of Website Quality Dimensions on Customer Satisfaction in the B2C E-commerce Context. Total Quality Management \& Business $\quad$ Excellence, 18(4), 363-378. https://doi.org/10.1080/14783360701231302

Luthfi, A. (2019, January). Ini Peta Persaingan E-Commerce Indonesia Q4 2018. Retrieved from https://techno.okezone.com/read/2019/01/30/207/2011416/ini-petapersaingan-e-commerce-indonesia-q4-2018

Meitiana. (2017). Perilaku Pembelian Konsumen: Sebuah Tinjauan Literatur Theory of Planned Behavior. Jurnal Ekonomi Modernisasi, 13(1), 16. https://doi.org/10.21067/jem.v13i1.1762

Nielsen, J. (2000). Designing Web Usability: The Practice of Simplicity. Indianapolis: New Riders Publishing.

Novak, T. P., Hoffman, D. L., \& Yung, Y. (2000). Measuring Online the Customer Experience in A Structural Environments: Modeling Approach. Marketing Science, 19(1), 22-42.

Ozkara, B. Y., Ozmen, M., \& Kim, J. W. (2017). Examining the effect of flow experience on online purchase: A novel approach to the flow theory based on hedonic and utilitarian value. Journal of Retailing and Consumer Services, 37, 119-131. https://doi.org/10.1016/j.jretconser.2017.04.001

Pee, L. G., Jiang, J., \& Klein, G. (2018). Signaling e ff ect of website usability on repurchase intention. International Journal of Information Management, 39, 228-241. https://doi.org/10.1016/j.ijinfomgt.2017.12.010

Poddar, A., Donthu, N., \& Wei, Y. (2009). Web site customer orientations , Web site quality, and purchase intentions: The role of Web site personality. Journal of Business Research, 62(4), 441-450. https://doi.org/10.1016/j.jbusres.2008.01.036

Putera, A. D. (2018, September). Jumlah Pembeli “Online” Indonesia Capai 11,9 Persen dari Populasi. from https://ekonomi.kompas.com/read/2018/09/07/164100326/jumlah-pembelionline-indonesia-capai-119-persen-dari-populasi 
Rayport, J. F., \& Jaworski, B. J. (2003). Introduction of E-commerce (Second Edi). Singapore: The McGraw-Hill Companies.

Ryu, K., \& Han, H. (2010). Relationships among hedonic and utilitarian value , satisfaction and behavioral intentions in the fast-casual restaurant industry. International Journal of Contemporary Hospitality Management, 22(3), 416-432. https://doi.org/10.1108/09596111011035981

Scarpi, D. (2012). Work and Fun on the Internet: The Effects of Utilitarianism and Hedonism Online. Journal of Interactive Marketing, 26(1), 53-67. https://doi.org/10.1016/j.intmar.2011.08.001

Schaupp, L. C., Bélanger, F., Fan, W., Christian, L., France, S., Weiguo, B., \& Tech, V. (2009). Examining the Success of Websites beyond E- Commerce: An Extension of the is Success Model. Journal of Computer Information Systems, 49(4), 42-52. https://doi.org/10.1080/08874417.2009.11645339

Setyowati, D. (2018, April). Indonesia, Modal Alibaba Jadikan Lazada Pemimpin Pasar E-Commerce. Retrieved from https://katadata.co.id/berita/2018/04/18/modal-alibaba-jadikan-lazadapemimpin-pasar-e-commerce-indonesia

Tandon, U., Kiran, R., \& Sah, A. N. (2017). Customer Satisfaction as Mediator Between Website Service Quality and Repurchase Intention: An Emerging Economy Case Customer Satisfaction as Mediator Between Website Service Quality and Repurchase Intention: An Emerging Economy Case, (May).

Tsao, W. C., Hsieh, M. T., \& Lin, M. . (2016). Intensifying online loyalty! The power of website quality and perceived value of the consumer/seller relationship. Industrial Management \& Data Systems, 116(9).

Vijay, T. S., Prashar, S., \& Parsad, C. (2017). Role of Shopping Values and Web Atmospherics in E-Satisfaction and Repurchase Intention, 2861(January). https://doi.org/10.1080/15332861.2016.1261544

Wu, L., Wang, Y., Wei, C., \& Yeh, M. (2015). Controlling information flow in online information seeking: The moderating effects of utilitarian and hedonic consumers. Electronic Commerce Research and Applications, 14(6), 603-615. https://doi.org/10.1016/j.elerap.2015.09.002

Yang, H. (2007). Assessing the effects of e-quality and e-satisfaction on website loyalty. International Journal of Mathematics and Computers in Simulation, $1(3)$.

Zhou, T. (2013). An empirical examination of continuance intention of mobile payment services. Decision Support Systems, 54(2), 1085-1091. 
https://doi.org/10.1016/j.dss.2012.10.034

Zhou, T., \& Zhang, S. (2009). Examining the Effect of E-commerce Website Quality on User Satisfaction. In Second International Symposium on Electronic Commerce and Security (pp. 418-421). https://doi.org/10.1109/ISECS.2009.24 